\title{
Article \\ Combined Acidification and Solar Drying of Pig Slurries for Nutrient Recovery and Controlled Atmospheric Emissions
}

\author{
Francesc X. Prenafeta-Boldú ${ }^{1, *} \mathbb{( D}$, Belén Fernández ${ }^{1}\left(\mathbb{D}\right.$, Marc Viñas ${ }^{1} \mathbb{D}$, Joan Noguerol $^{1}{ }^{\mathbb{C}}$, Joan Soler $^{2}$ \\ and Josep Illa ${ }^{3}$ (D) \\ 1 GIRO Program, Institute of Agrifood Research and Technology (IRTA), Torre Marimon, \\ 08140 Caldes de Montbui, Spain; belen.fernandez@irta.cat (B.F.); marc.vinas@irta.cat (M.V.); \\ joan.noguerol@irta.cat (J.N.) \\ 2 EMA Depuració, Avda. Sant Jordi 176, 17800 Olot, Spain; adm@edepura.com \\ 3 Department of Computing and Industrial Engineering, Universitat de Lleida, Avgda. Jaume II 69, \\ E-25001 Lleida, Spain; jilla@macs.udl.cat \\ * Correspondence: francesc.prenafeta@irta.cat; Tel.: +34-93-467-4040
}

Citation: Prenafeta-Boldú, F.X.;

Fernández, B.; Viñas, M.; Noguerol, J.; Soler, J.; Illa, J. Combined

Acidification and Solar Drying of Pig Slurries for Nutrient Recovery and Controlled Atmospheric Emissions. Agronomy 2021, 11, 222. https:// doi.org/10.3390/agronomy11020222

Received: 28 December 2020

Accepted: 21 January 2021

Published: 25 January 2021

Publisher's Note: MDPI stays neutral with regard to jurisdictional claims in published maps and institutional affiliations.

Copyright: (c) 2021 by the authors. Licensee MDPI, Basel, Switzerland. This article is an open access article distributed under the terms and conditions of the Creative Commons Attribution (CC BY) license (https:/ / creativecommons.org/licenses/by/ $4.0 /)$.

\begin{abstract}
The solar drying of pig slurries was tested in a pilot-scale greenhouse (10 $\mathrm{m}^{2}$ footprint), operated with forced ventilation under low and high solar irradiation in Mediterranean conditions. Gaseous emissions were prevented through slurry acidification and by the biofiltration of exhaust gases. Air relative humidity and temperature in and out the greenhouse, as well as the weight of a slurry sample, were monitored online to command the ventilation regime. Daily average drying rate values ranged from 0.3 to $2.8 \mathrm{~kg} \mathrm{~m}^{-2} \mathrm{~d}^{-1}$ and displayed a direct dependency with solar radiation until the pig slurry lost a $60 \%$ of its initial weight, with a solar energy efficiency of about $26 \%$. Upon further drying, the water content from pig slurries stabilized at around $10 \%$. Mass balances between the initial slurry and dried product were closed for total solids and organic matter, but the recovery of nutrients ranged from $69 \%$ to $81 \%$, apparently because of precipitation and incrustation phenomena. The NPK composition of the final product was 4.3-2.5-3.8 and fulfilled current regulations for solid organic fertilizers. Operational costs of the drying process and fertilizing quality parameters were also discussed.
\end{abstract}

Keywords: acidification; air biofiltration; dynamic drier; manure; nutrient recovery; organic fertilizers; solar energy

\section{Introduction}

Intensive livestock farming has led to the production of large amounts of manure, which contain more nutrients than what the bystanding crops are able to extract [1]. This manure excess causes significant nitrate and phosphate pollution of water bodies and soils, but it also results in harmful atmospheric emissions (greenhouse gases, ammonia, malodors, etc.). Therefore, manure generation, management, and application has been subjected to increasing regulatory restrictions [2]. Paradoxically, crop productivity is still sustained in a large degree thanks to the application of mineral fertilizers that are obtained from nonrenewable resources (i.e., extracted phosphate rock and ammonia synthesis through the energy intensive Haber-Bosch process). The key to a sustainable manufacture and export of organic fertilizers from manure is the on-site concentration of nutrients by removing its water, either by physical separation methods [3], chemical precipitation [4], or through thermal or vacuum evaporation [5]. However, these manure processing technologies require energy, chemical reagents, and costly infrastructure.

Some of the densest livestock production areas worldwide are located in regions that are exposed to a high solar radiation, such as Catalonia, in south Europe. Several biomass drying technologies based on capturing radiant energy from the sun have been devised [6,7]. The most efficient systems commonly make use of greenhouses, which are 
essentially enclosed structures that trap short wavelength solar radiation and store long wavelength thermal radiation to create a favorable drying environment, while moisture is removed either through natural convection or by forced ventilation. Extensive reviews have been published on the use of greenhouses for the dehydration of agricultural and food products [8,9], but also for the drying of sewage sludge $[10,11]$.

Experiences of greenhouse solar drying on animal dejections have also been performed, but those accounts are mainly limited to poultry manure [12]. Instead, reports on the application of greenhouses for the drying of animal slurries are practically inexistent. The main concern upon the application of thermal drying processes to animal dejections is the volatilization of ammonia and other malodorous compounds. In a previous study on the solar drying of pretreated sewage sludge, nitrogen losses due to ammonia volatilization ranged from $22 \%$ to $74 \%$, depending on the source and treatment technology [13]. The use of an acid scrubber for the absorption of gaseous ammonia was suggested in that study. A Drechsler trap (a type of acid scrubber for the absorption of ammonia) was used in the solar drying of digestates from different origins [14]. Recently, the direct acidification of animal dejections has been proposed as a suitable solution to prevent the volatilization of ammonia during the storage and processing of manure [15].

In the present study, a pilot-scale greenhouse system was assayed for the solar drying of freshly collected pig slurries. The drying rate (i.e., the daily mass loss of pig slurries) and environmental parameters in and out of the greenhouse were monitored online. Ammonia losses were controlled through acidification of the slurries and by treating the emitted gases in an air biofilter. Special attention was given to the emission of greenhouse gases (carbon dioxide, methane, and nitrous oxide), ammonia, and hydrogen sulfide, as well as to the global mass balance of nutrients and energy. Physicochemical and microbial quality parameters from the dehydrated material obtained are also discussed, with a view on its potential use as an organic fertilizer.

\section{Materials and Methods}

\subsection{Experimental Setup}

The solar drying pilot plant used in this study was installed at the facilities of IRTATorre Marimon $\left(41^{\circ} 36^{\prime} 43.57^{\prime \prime} \mathrm{N} ; 2^{\circ} 10^{\prime} 10.76^{\prime \prime} \mathrm{E}\right)$. The plant comprised a greenhouse and a biofilter for the treatment of emitted gases (Figure 1); the most relevant design and operational parameters of this installation are summarized in Table 1. The greenhouse was designed as a Quonset shape (a semicylindrical tunnel). A structural frame made of PVC tubes (32 mm in diameter) supported a $200 \mu \mathrm{m}$ low-density polyethylene sheet, while a $400 \mu \mathrm{m}$ PET sheet was used at the base of the greenhouse in order to contain the pig slurries. The greenhouse was mounted on a concrete floor isolated with a geotextile sheet, in order to provide further thermal isolation and physical protection from the ground. A sensor for monitoring temperature and relative humidity (EWHS 284, Eliwell, Valencia, Spain) was placed at the middle of the greenhouse, and a second identical sensor was installed outdoors. Furthermore, an electronic scale for the continuous weighing of water evaporation in a pig slurry sample loaded on a tray of approximately $20 \times 30 \mathrm{~cm}$ was installed at the final section of the greenhouse, close to the air exhaust. All sensors were connected to a datalogger (DOP-B03E211, Delta Electronics Inc., Tainan City, Taiwan), and data measurements were recorded every 15 or $30 \mathrm{~min}$.

Air from the greenhouse was extracted with a ventilator ( $66 \mathrm{~W}$ of power and a nominal flow of $1 \mathrm{~m}^{3} \mathrm{~min}^{-1}$ ) and forced into the gas biofilter. The ventilator was activated according to the following regime: (a) activate aeration after 8:00 a.m. and deactivate it after 20:00, and (b) activate only if the relative humidity in the interior of the greenhouse was more than $50 \%$. The biofilter bed consisted of a mixture of ripe compost and pine bark (1:5 mass ratio, $113 \mathrm{~L}$ of packed volume) and was encased in a PVC tube (31.5 cm of diameter). A sampling port was set at the biofilter inlet and outlet for the monitoring and withdrawal of gas samples. 

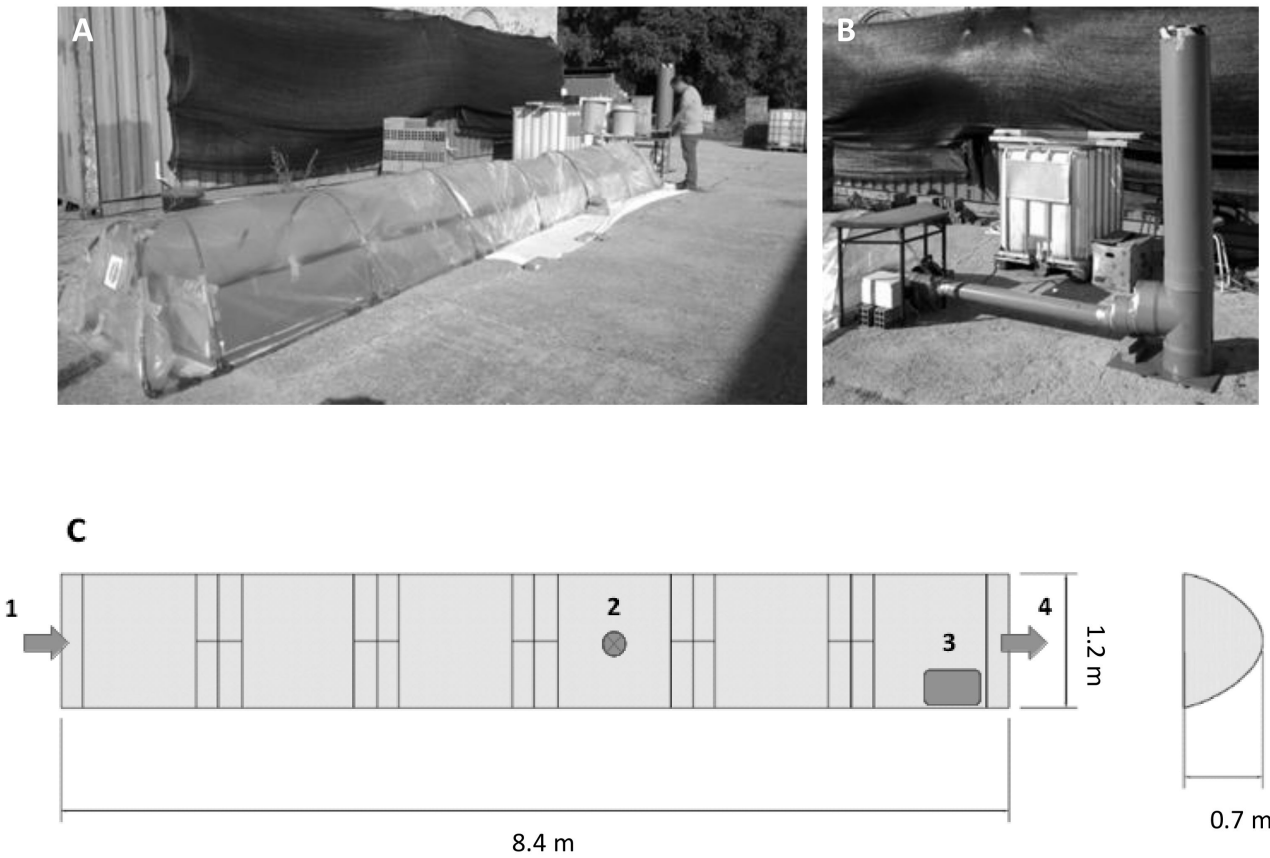

Figure 1. Images of the pilot-scale solar drying greenhouse (A) and the biofilter for treating the exhaust gases (B), and schematic representation $(\mathbf{C})$ of the greenhouse design and dimensions: air inlet (1), indoor temperature and relative humidity sensor (2), mass scale (3), and air exhaust (4).

Table 1. Design and operational parameters of the pilot plant (Figure 1).

\begin{tabular}{ccc}
\hline Parameter & Type/Value & Unit \\
\hline Shape & Greenhouse & - \\
Width & Quonset & $\mathrm{m}$ \\
Length & 1.2 & $\mathrm{~m}$ \\
Height & 8.4 & $\mathrm{~m}$ \\
Volume (approx.) & 0.7 & $\mathrm{~m}^{3}$ \\
Covered surface & 6.5 & $\mathrm{~m}^{2}$ \\
\hline & 10 & \\
Air flux (nominal) & Aeration and Biofiltration & $\mathrm{m}^{3} \mathrm{~min}^{-1}$ \\
Renovation time & 1 & $\mathrm{~min} \mathrm{renov}^{-1}$ \\
Biofilter shape & 6.5 & - \\
Packing material & Cylindrical & - \\
Diameter & Pine bark/compost & $\mathrm{m}$ \\
Packing height & 0.315 & $\mathrm{~m}^{3}$ \\
Packing volume & 1.500 & $\mathrm{~m}$ \\
Gas residence time & 0.117 & $\mathrm{~s}$ \\
\hline
\end{tabular}

${ }^{a}$ Time required by the ventilation system to pump an air volume equivalent to that of the greenhouse.

Pig slurries were distributed homogenously inside the greenhouse and remained static until the end of the drying trial. The total amount of loaded pig slurry and the extracted dried fraction was weighed by a load cell (maximum standard error $1 \%$ ). Samples (approximately $100 \mathrm{~g}$ ) were taken in triplicate after mixing pig slurries and dried fractions thoroughly, for subsequent physicochemical and microbiological analysis in the laboratory. Gas samples from the biofilter inlet and outlet were taken throughout the drying process by means of a calibrated sampling pump (flow of $1 \mathrm{~L} \mathrm{~min}^{-1}$ ) and stored in a $3 \mathrm{~L}$ volume gas sampling bag (SamplePro FlexFilm), for the analysis of greenhouse gases in the laboratory within $24 \mathrm{~h}$. Hydrogen sulfide was captured in a carbon adsorption tube by means of a sampling pump calibrated at a flow rate of $0.2 \mathrm{~L} \mathrm{~min}^{-1}$, equipped with a Teflon prefilter to prevent interference of sulfates. 
Data on the daily temperature (mean, maximum, and minimum), relative humidity, precipitation, and solar radiation were obtained from the meteorological station of Caldes de Montbui $\left(41^{\circ} 36^{\prime} 45.54^{\prime \prime} \mathrm{N}, 2^{\circ} 10^{\prime} 6.10^{\prime \prime} \mathrm{E}\right)$, located about $100 \mathrm{~m}$ away from the greenhouse. This meteorological station belongs to the Meteorological Service of Catalonia and the historical meteorological data used in this study can be obtained online (https: / / www. meteo.cat/).

\subsection{Analytical Methods}

The used pig slurries and the obtained dried material were characterized in terms of $\mathrm{pH}$, total and volatile solids (TS/VS), chemical oxygen demand (COD), total nitrogen $(\mathrm{Nt})$, total ammonia nitrogen (TAN), nitrites and nitrates $\left(\mathrm{NO}_{2}{ }^{-}, \mathrm{NO}_{3}{ }^{-}\right)$, total phosphorus, $(\mathrm{Pt})$, phosphate $\left(\mathrm{PO}_{4}{ }^{3-}\right)$, total potassium $(\mathrm{Kt})$ and sulfate $\left(\mathrm{SO}_{4}{ }^{2-}\right)$, following the Standard Methods for the Examination of Water and Wastewater [16]. Heavy metals $(\mathrm{Cd}, \mathrm{Cu}, \mathrm{Ni}$, $\mathrm{Pb}, \mathrm{Zn}, \mathrm{Hg}$, and $\mathrm{Cr}$ ) were analyzed by inductively coupled plasma-mass spectrometry (ICP-MS), according to the USA Environmental Protection Agency (EPA Method 6020). The presence of viable bacteria belonging to the species Escherichia coli and Salmonella spp. were quantified in cultures according to the EPA Methods 1103.1 [17] and 1682 [18]. The concentration of ammonia at the biofilter inlet and outlet was measured in situ with a portable electrochemical sensor (VRAE, RAE Systems, San Jose, CA, USA). Two different gas chromatography (GC) methods were used for the analysis of gases in the laboratory. Methane was quantified with a Thermo 2000 GC equipped with a flame ionization detector (FID), in accordance with the method described by Palatsi et al. [19]. The simultaneous analysis of carbon dioxide and nitrous oxide was carried out with an Agilent 7890A GC equipped with an electron capture detector (ECD), similar to that described by MartínezEixarch et al. [20]. Hydrogen sulfide was desorbed and measured in the laboratory by ion chromatography according to the USA National Institute for Occupational Safety and Health (NIOSH Method 6013).

\subsection{Calculations}

The total content of specific compounds in fresh and acidified pig slurries, and in the final dried fraction, was calculated as the product of the average mass and concentration values. Propagation errors on the resulting absolute content were derived from the mass and concentration standard deviations/errors, assuming that both variables were independent. Mass balances were then performed on selected components (total mass, water, total solids, organic matter, nitrogen, phosphorus, potassium, sulfur, sodium, calcium and manganese), between fresh and acidified pig slurry, and between fresh and dried fraction. Significant differences in total content values were established by one-way ANOVA and a Tukey-Kramer HSD post hoc test was performed on pairwise treatment comparisons. The mass loss through water evaporation and the volatilization of carbon and nitrogen compounds via the extracted gases was also determined as the product of the total vented air volume, estimated from the pump flow and operation time, and the average concentration of selected gases from three measurements performed throughout the experiment.

\section{Results and Discussion}

\subsection{Process Performance}

Two experimental solar drying runs were performed at low (autumn, from 6 October 2014 to 24 October 2014) and high (spring, from 14 April 2015 to 30 April 2015) solar irradiation conditions. Daily meteorological parameters during these trials are summarized in the Supplementary Table S1. During the first trial, the greenhouse was loaded with $260 \mathrm{~kg}$ of freshly collected slurry from a farrowing farm, which had previously been acidified to a $\mathrm{pH}$ of 3.3. Meteorological parameters during the first trial were characteristic from the autumn seasons under Mediterranean conditions, with sporadic rains and variable average daily temperatures between 8.1 and $19.7^{\circ} \mathrm{C}$ (minimum $2.1^{\circ} \mathrm{C}$ and maximum $28.6^{\circ} \mathrm{C}$ ). The daily average relative humidity and solar radiation during this same period ranged $62-89 \%$ 
and 3.5-16.9 MJ, respectively. Inside the greenhouse, the daily average temperature during the test varied between 19.7 and $27.6^{\circ} \mathrm{C}$, with a record high peak of $45.6^{\circ} \mathrm{C}$, and a daily average relative humidity that ranged between $76.8 \%$ and $91.5 \%$. The weight from the pig slurry sample $(4.6 \mathrm{~kg})$ placed inside the greenhouse displayed a regular decreasing pattern during operation, corresponding to a daily drying rate of $1.42 \mathrm{~kg} \mathrm{~m}^{-2} \mathrm{~d}^{-1}$ until a total weight loss of a 33\% (Figure 2). The greenhouse operation had to be stopped thereafter because of technical problems and bad weather conditions. At this point, the dried fraction displayed a strong humidity gradient along the greenhouse length, with values in the content of TS that ranged from $89.00 \%$ at the air inlet to $3.34 \%$ at the outlet. The ventilation system during this time was activated for $176 \mathrm{~h}, 39 \%$ of the total operational time.
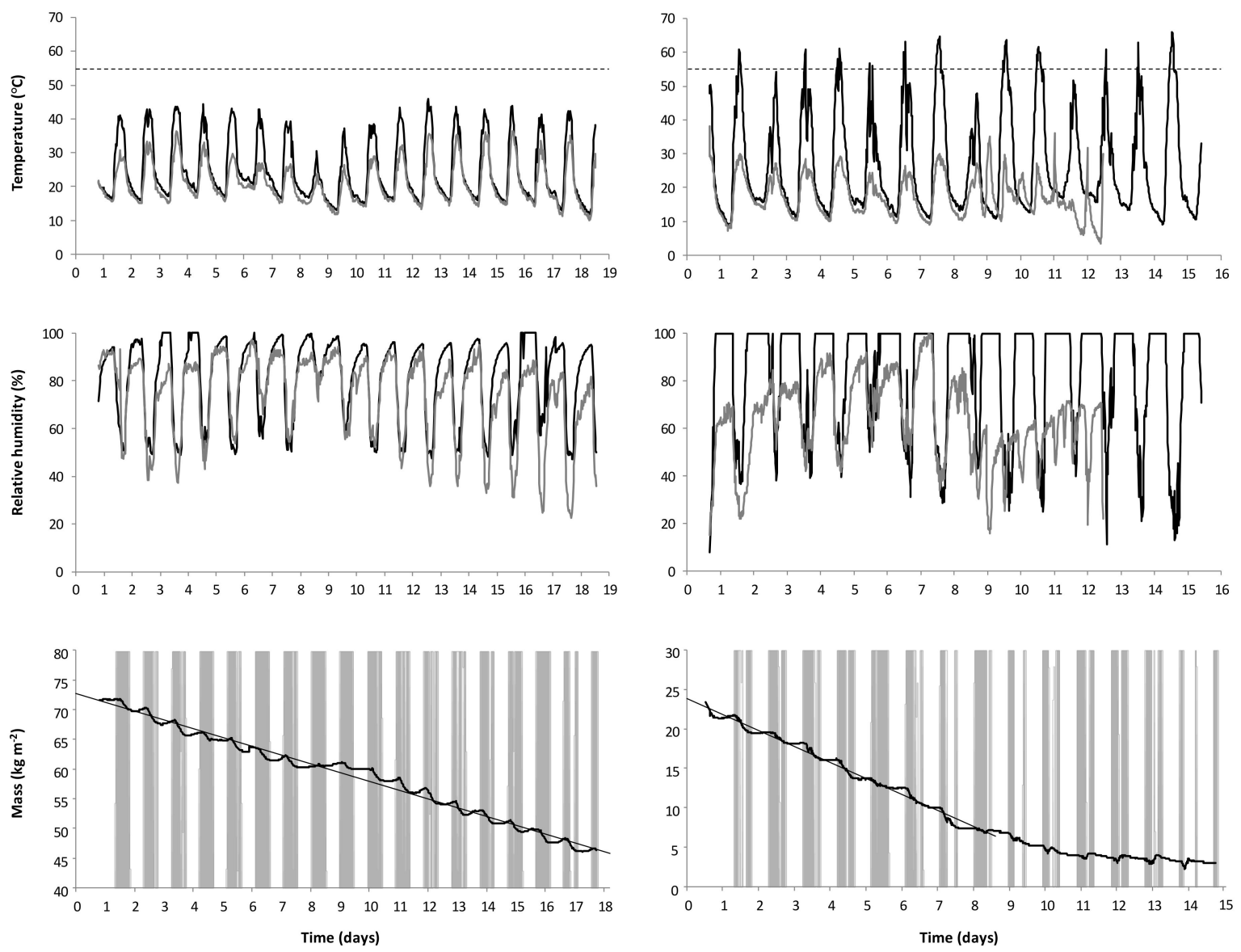

Figure 2. Summary of operational parameters during the solar drying trials in November (left) and April (right): Timecourse evolution of the temperature (top figures) and relative humidity (middle figures), inside (black line), and outside (gray line) the greenhouse; the dashed line points to temperatures above $55{ }^{\circ} \mathrm{C}$. The bottom graphs display the continuous monitoring of a pig slurry sample weight inside the greenhouse (solid line) and the ventilation intervals (gray bars); the linear regression lines correspond to average daily evaporation rate of 1.42 and $1.93 \mathrm{~kg} \mathrm{~m}^{-2} \mathrm{~d}^{-1}$, respectively for trials 1 and $2\left(n \geq 800, r^{2}=0.99\right)$.

The results obtained during this first experiment were used to refine the setup of the second experiment, in which the greenhouse was loaded with $315 \mathrm{~kg}$ of freshly collected slurry from a pig fattening farm that was acidified to a $\mathrm{pH}$ of 4.70. Meteorological parameters remained relatively stable during the second trial, with sunny days and average daily temperatures between 13 and $16{ }^{\circ} \mathrm{C}$ (minimum $4{ }^{\circ} \mathrm{C}$ and maximum $25^{\circ} \mathrm{C}$ ), while the relative humidity ranged between $42 \%$ and $84 \%$, and the solar radiation during this period ranged from 13 to $27 \mathrm{MJ} \mathrm{m}^{-2}$. The daily average temperature inside the greenhouse during the test varied between $23^{\circ} \mathrm{C}$ and $30^{\circ} \mathrm{C}$ (record high peak of $63^{\circ} \mathrm{C}$ ), and the daily average relative humidity ranged $72-100 \%$. A regular drying pattern was observed for a 
pig slurry sample $(1.63 \mathrm{~kg}$ ) during the first 8 days of operation, with a daily drying rate of $1.93 \mathrm{~kg} \mathrm{~m}^{-2} \mathrm{~d}^{-1}$ and a weight reduction of the $67 \%$ (Figure 2). At that point, the ventilation system had been active during $77.5 \mathrm{~h}$, which corresponds to a $37 \%$ of the run time until then. The operation was extended for 4 additional days, during which the weight of the slurry sample stabilized at approximately the $13 \%$ of its initial mass. The experimental run was stopped after 15.5 days of operation, upon appreciation of significant drying of the pig slurries inside the greenhouse. The daily maximum and minimum evaporation rates, measured from the weighted slurry sample were reported subsequently on days 7 and 8 , respectively. The highest hourly evaporation rate in the former was measured around the astronomical noon and corresponded to $0.41 \mathrm{~kg} \mathrm{~m}^{-2} \mathrm{~h}^{-1}$, while no significant evaporation occurred in the latter. These two days also displayed the highest and the lowest daily cumulative solar radiation, with 26 and $13 \mathrm{MJ} \mathrm{m}^{-2}$.

Interestingly, a slight mass gain was observed in both trials during the night/morning hours when the ventilation system was off, especially towards the end of the experiment, when pig slurries were relatively dehydrated (Figure 2). This phenomenon points to the fact that pig slurries, like many salt solutions, might display hydroscopic properties and rehydrate under relatively high humidity conditions. When comparing the cumulative daily evaporation with that resulting from the difference between the daily maximum and minimum water content, thus excluding rehydration from the global balance, it became apparent that the hygroscopic behavior of pig slurry reduced the process efficiency from $8 \%$ in the second trial up to $59 \%$ during the first one, when the outdoor RH and T values where less favorable to evaporation (Figure 2). The humidity in the dried material tended to concentrate at the inner core of agglomerated particles, and mixing of the slurries inside the greenhouse is a common practice to enhance the drying process at industrial scale [7-10].

The measured daily average evaporation rate was linearly correlated to the solar radiation interval between 10 and $30 \mathrm{MJ} \mathrm{m}^{-2}$, with estimated drying rates ranging from 0.4 to $3.8 \mathrm{~kg} \mathrm{~m}^{-2}$ (Figure 3). This drying performance is similar to that obtained with a similar experiment using the same setup for the dehydration of activated sludge from a winery wastewater treatment plant [11], suggesting that pig slurries have similar dehydration behavior to that of sewage sludge.

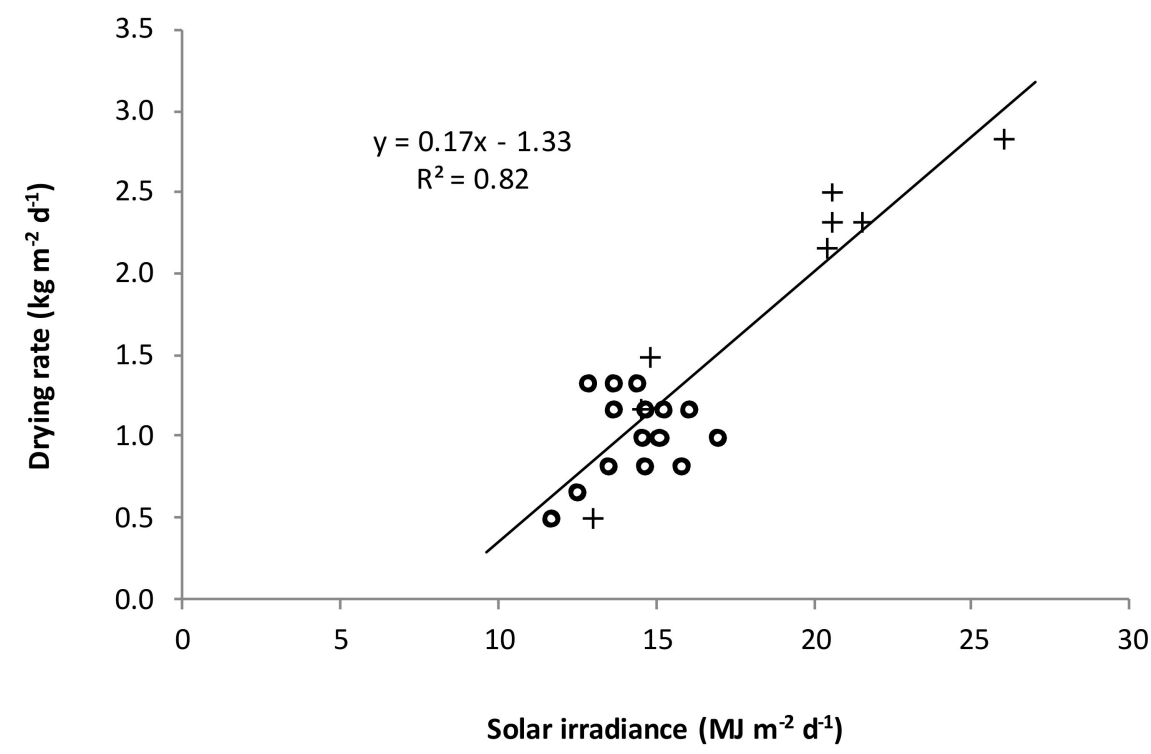

Figure 3. Correlation between the daily solar radiation and weight loss inside the greenhouse due primarily to water evaporation, during the first of days of relative steady drying of trials 1 (circles) and 2 (crosses), as determined from the data of Figure 2 (only irradiances above $10 \mathrm{MJ} \mathrm{m}^{-2} \mathrm{~d}^{-1}$ were considered). 


\subsection{Chemical Characterization and Atmospheric Emissions}

During the second trial, freshly collected pig slurry and the acidified fractions generated before and after drying were characterized in physicochemical terms (Table 2). Despite the heterogeneity of these materials, the relative standard deviation obtained for the parameters determined by triplicate was generally below $10 \%$. The pig slurry composition corresponded to that from a rather typical pig fattening farm in Catalonia [21]. Concerning the different nitrogen species, the concentration $\mathrm{Nt}$ was $7.2 \mathrm{~g} \mathrm{~N} \mathrm{~kg}^{-1}$, while TAN was $5.1 \mathrm{gN} \mathrm{kg}^{-1}$. The presence of nitrite was not detected and a small amount of nitrate could be quantified before acidification $\left(30.9 \mathrm{mg} \mathrm{NO}_{3}{ }^{-}-\mathrm{N} \mathrm{kg}^{-1}\right)$.

Table 2. Chemical composition of fresh and acidified pig slurries from a fattening farm, and of the dried fraction after 16 days of treatment (second trial). Some of the values correspond to the average and standard deviation (between brackets) of three independent samples.

\begin{tabular}{|c|c|c|c|c|c|c|c|}
\hline \multirow{3}{*}{$\begin{array}{c}\text { Parameter }^{a} \\
\mathrm{pH}\end{array}$} & \multirow{3}{*}{$\begin{array}{c}\text { Units } \\
-\end{array}$} & \multicolumn{4}{|c|}{ Initial Conditions ( $\mathrm{t}=\mathbf{0}$ days) } & \multirow{2}{*}{\multicolumn{2}{|c|}{$\begin{array}{c}\text { Final Conditions }(t=16 \text { days }) \\
\text { Dried Fraction }\end{array}$}} \\
\hline & & \multicolumn{2}{|c|}{ Fresh Slurry } & \multicolumn{2}{|c|}{ Acidified Slurry } & & \\
\hline & & 7.70 & & 4.37 & & - & \\
\hline TS & $(\%)$ & 10.53 & $(0.06)$ & 11.69 & $(0.54)$ & 89.60 & $(0.06)$ \\
\hline VS & $(\%)$ & 7.76 & $(0.06)$ & 8.30 & $(0.35)$ & 66.02 & $(0.69)$ \\
\hline COD & $\left(\mathrm{g} \mathrm{O}_{2} \mathrm{~kg}^{-1}\right)$ & 128.52 & (9.79) & 120.56 & $(8.80)$ & 965.80 & $(60.76)$ \\
\hline $\mathrm{Nt}$ & $\left(\mathrm{mg} \mathrm{N} \mathrm{kg}^{-1}\right)$ & 7178.86 & (49.13) & 6830.43 & $(23.59)$ & $43,144.65$ & (193.36) \\
\hline TAN & $\left(\mathrm{mg} \mathrm{N} \mathrm{kg}^{-1}\right)$ & 5059.99 & $(78.75)$ & 4697.99 & (21.95) & $29,340.00$ & $(333.00)$ \\
\hline $\mathrm{NO}_{2}{ }^{-}-\mathrm{N}$ & $\left(\mathrm{mg} \mathrm{N} \mathrm{kg}^{-1}\right)$ & $<0.6$ & & $<0.6$ & & $<0.6$ & \\
\hline $\mathrm{NO}_{3}{ }^{-}-\mathrm{N}$ & $\left(\mathrm{mg} \mathrm{N} \mathrm{kg}^{-1}\right)$ & 30.85 & $(0.05)$ & $<0.5$ & & $<0.5$ & \\
\hline $\mathrm{Pt}$ & $\left(\mathrm{mg} \mathrm{P} \mathrm{kg}{ }^{-1}\right)$ & 1620.00 & $(130.00)$ & 1677.00 & $(83.00)$ & $10,947.00$ & $(101.00)$ \\
\hline $\mathrm{PO}_{4}{ }^{3-}-\mathrm{P}$ & $\left(\mathrm{mg} \mathrm{P} \mathrm{kg}^{-1}\right)$ & 20.09 & $(0.17)$ & 1610.19 & $(6.62)$ & 9330.53 & $(9.26)$ \\
\hline $\mathrm{SO}_{4}^{2-}-\mathrm{S}$ & $\left(\mathrm{mg} \mathrm{S} \mathrm{kg}^{-1}\right)$ & 101.78 & $(2.02)$ & 8559.21 & $(100.56)$ & $43,240.84$ & $(284.57)$ \\
\hline $\mathrm{Na}^{+}$ & $\left(\mathrm{mg} \mathrm{Na} \mathrm{kg}{ }^{-1}\right)$ & 1503.82 & $(25.58)$ & 1412.70 & $(89.49)$ & 7256.29 & $(219.70)$ \\
\hline $\mathrm{K}^{+}$ & $\left(\mathrm{mg} \mathrm{K} \mathrm{kg} \mathrm{Kg}^{-1}\right)$ & 5499.27 & (15.07) & 5671.02 & (110.41) & $31,462.52$ & $(346.15)$ \\
\hline $\mathrm{Ca}^{2+}$ & $\left(\mathrm{mg} \mathrm{Ca} \mathrm{kg}^{-1}\right)$ & 1671.88 & (73.78) & 2199.17 & $(97.23)$ & 5092.41 & $(168.28)$ \\
\hline
\end{tabular}

${ }^{a}$ TS: total solids; VS: volatile solids; COD: chemical oxygen demand; Nt: total nitrogen; TAN: total ammonia nitrogen; $\mathrm{NO}_{2}{ }^{-}-\mathrm{N}$ : total nitrite nitrogen; $\mathrm{NO}_{3}{ }^{-}-\mathrm{N}$ : total nitrate nitrogen; Pt: total phosphorus; $\mathrm{PO}_{4}{ }^{3-}$-P: total phosphorus as phosphate; $\mathrm{SO}_{4}{ }^{2-}-\mathrm{S}$ : total sulfur as sulfate; $\mathrm{Na}^{+}$: sodium; $\mathrm{K}^{+}$: potassium; $\mathrm{Ca}^{2+}$ : calcium.

The concentration of ammonia, nitrous oxide, methane, carbon dioxide and hydrogen sulfide was monitored at the greenhouse inlet (background air) and exhaust (biofilter inlet), as well as at the final discharge (biofilter outlet), during the second trial (Table 3). Relatively low concentrations of ammonia were detected at the greenhouse exhaust/biofilter inlet (0.5-1.0 $\left.\mathrm{mg} \mathrm{NH}_{3}-\mathrm{N} \mathrm{m}^{-3}\right)$, but the concentration of this compound in the biofilter outlet was below the detection level of the sensor $\left(<0.35 \mathrm{mg} \mathrm{NH}_{3}-\mathrm{N} \mathrm{m}^{-3}\right)$. On the other hand, the concentration of greenhouse gases (methane and nitrous oxide) at the biofilter inlet and outlet were not significantly different from those present in the background air. Concerning the impact of odor emissions, the average concentration of hydrogen sulfide of $1.45 \mathrm{mg} \mathrm{m}^{-3}$ (Table 3) was above the odor threshold of $12 \mu \mathrm{g} \mathrm{m}^{-3}$ [22], and could be clearly perceived during the olfactory assessment. However, the reported concentrations remained well below the threshold limit value for occupational exposure of $14 \mathrm{mg} \mathrm{m}^{-3}$ for this compound. Furthermore, about $60 \%$ of the emitted hydrogen sulfide was removed in the air biofilter. A qualitative appreciation of the odor character from the biofilter off-gases based on descriptors typical from waste materials [23] highlighted the improved olfactory perception of the greenhouse exhaust air after treatment by biofiltration (Table 3).

The emission of sulfide might be attributed to the pig slurry acidification with sulfuric acid and to the metabolism of sulfate-reducing bacteria. This group of microorganisms competes with the methanogens under anaerobic conditions by using sulfate as the electron acceptor and reducing it to hydrogen sulfide. Furthermore, the prevailing aerobic conditions due to the thin water sheet, the relatively low $\mathrm{pH}$, and the fluctuating temperature conditions, might also limit the microbial activity of anaerobic microorganisms, thus 
preventing methane emissions. The concentration of carbon dioxide at the greenhouse exhaust was a $21 \%$ higher than in the background air (Table 3 ), indicating a certain degree of microbial aerobic activity, despite the imposed growth limiting conditions.

Table 3. Average and standard deviation (indicated between brackets, from three measurements taken at days 1, 8, and 16) of the concentration of selected contaminants in the air biofilter inlet and outlet during the second trial. The odor sensory descriptors in the air from the biofilter inlet and outlet, the removal efficiency, and the composition of the outdoor air are also indicated.

\begin{tabular}{|c|c|c|c|c|c|c|}
\hline \multirow{2}{*}{$\begin{array}{c}\text { Parameter } \\
\text { Carbon dioxide }\end{array}$} & \multirow{2}{*}{$\begin{array}{c}\begin{array}{c}\text { Outdoor Air } \\
\left.\text { (mg m }^{-3}\right)\end{array} \\
1016\end{array}$} & \multicolumn{2}{|c|}{$\begin{array}{l}\text { Biofilter Inlet } \\
\quad\left(\mathrm{mg} \mathrm{m}^{-3}\right)\end{array}$} & \multicolumn{2}{|c|}{$\begin{array}{l}\text { Biofilter Outlet } \\
\left(\mathrm{mg} \mathrm{m}^{-3}\right)\end{array}$} & \multirow{2}{*}{$\begin{array}{c}\begin{array}{c}\text { Removal } \\
\text { Efficiency (\%) }\end{array} \\
6.9\end{array}$} \\
\hline & & 1229 & (237) & 1144 & $(218)$ & \\
\hline Methane & 1.80 & 1.57 & $(0.153)$ & 1.60 & $(0.346)$ & 0.0 \\
\hline Ammonia & nd $^{a}$ & 0.75 & $(0.375)$ & $\mathrm{nd}^{a}$ & - & $>53.3^{b}$ \\
\hline Nitrous oxide & 0.79 & 1.04 & $(0.172)$ & 1.02 & $(0.167)$ & 1.9 \\
\hline Hydrogen sulfide & 0.0005 & 1.45 & $(0.212)$ & 0.55 & $(0.071)$ & $62.1^{c}$ \\
\hline Odor descriptors & - & \multicolumn{2}{|c|}{$\begin{array}{l}\text { Fatty } \\
\text { Sulfur } \\
\text { Fecal }\end{array}$} & \multicolumn{2}{|c|}{$\begin{array}{l}\text { Earthy } \\
\text { Musty } \\
\text { Terpene }\end{array}$} & - \\
\hline
\end{tabular}

${ }^{a}$ Below the limit of detection (LOD) for ammonia $\left(0.35 \mathrm{mg} \mathrm{m}^{-3}\right) \cdot{ }^{b}$ Statistical significance of $p<0.061$ between biofilter inlet and outlet concentrations; the LOD/ 2 and the "range rule of thumb" were used for estimating the mean and the standard deviation, respectively. ${ }^{c}$ Statistical significance at $p<0.002$ between biofilter inlet and outlet concentrations.

\subsection{Mass and Energy Balances}

Mass balances were performed on the content of different fractions and chemical compounds present in the fresh and acidified slurries, and in the final dried material of the second trial (Table 4). The acidification of pig slurry had little effect on the mass balance of water/total solids, organic matter, nitrogen, phosphorus, potassium, and sodium. But, in addition to the expected increase of sulfate due to the added sulfuric acid, it significantly increased the amounts of calcium and manganese as well. As for the drying process, the initial $321 \mathrm{~kg}$ of acidified pig slurries were reduced to $40 \mathrm{~kg}$ of dried fraction, an $88 \%$ mass decrease. Most of this loss must correspond to evaporated water which, based on the total solids of the acidified slurry and the dried fraction, amounted to $279 \mathrm{~kg}$.

Mass balances between acidified and dried slurries were rather accurate for total solids and organic matter, with closing errors within the $\pm 5 \%$ range (Table 4 ). Carbon loss via methane emissions were nonsignificant while about $3 \%$ of initial carbon might have been lost as carbon dioxide. As for nitrogen, only $78 \%$ of the total content was recovered with the final dry fraction. Considering the low level of measured ammonia emissions due to acidification, this significant gap in the nitrogen mass balance might be attributed to sampling errors at the relatively bulky scale of the pilot plant. Nonvolatile substances such as phosphorus, potassium, sodium, and manganese also displayed similar recoveries in the dried fraction, ranging from $63 \%$ to $81 \%$, although for calcium recovery it was as low as $29 \%$. A likely explanation for this phenomenon is the formation of fine mineral-like precipitates on the PET foil used to contain the liquid slurry, which could not be properly recovered with the dried fraction. The precipitation of phosphate and ammonia as struvite crystals is a well-known phenomenon in pig slurries, which occurs at relatively high $\mathrm{pH}$ values when calcium and magnesium are present, but it might also take place under increased ionic strength [3].

In what relates to the energy balance, considering that under normal conditions the vaporization enthalpy of water is $2.442 \mathrm{MJ} \mathrm{kg}^{-1}$ and that from days 1 to 8 of steady drying about $163 \mathrm{~kg}$ of water were effectively evaporated, at least $398 \mathrm{MJ}$ were needed for this purpose. On the other hand, the cumulative incident solar radiation on the greenhouse footprint during this same period was of $1514 \mathrm{MJ}$ (Table S1). Hence, such energy balance corresponds to an average solar energy efficiency of $26 \%$. The remaining energy fraction might have been initially reflected by the greenhouse cover, reemitted to the environment 
as thermal radiation, lost through conduction into the ground, and via convection with the extracted hot air. Concerning the nonsolar energy inputs, taking into account the nominal electrical power of the air pump $(66 \mathrm{~W})$ and its the working time of $74.5 \mathrm{~h}$ during steady drying phase, it was estimated that about $17.7 \mathrm{MJ}$ were consumed. Since $1.717 \mathrm{~kg}$ of nitrogen were recovered with the final dried fraction, this corresponded to a specific electricity consumption of $2.9 \mathrm{~kW} \mathrm{~h}$ per $\mathrm{kg}$ of separated nitrogen. This value is well below the energy requirements reported for conventional mechanical separation units, which range from 4.3 to $7.9 \mathrm{~kW}$ h per $\mathrm{kg}$ of nitrogen recovered in the solid fraction [24]. Furthermore, mechanical systems display separation efficiencies in the final solid fraction (30-70\% for total solids, 9-29\% for nitrogen, and 60-90\% for phosphorus, depending on the technology and the use of flocculants) that are significantly lower than those reported in this work, and are also prone to higher atmospheric emissions. Yet, the economic cost and hazards of applying a concentrated acid must be considered as an inconvenience of the solar drying technology, along with the large footprint required by the greenhouse and the seasonality of solar irradiation.

Table 4. Average and standard deviation (between brackets) of mass fractionation values of selected chemical categories in freshly collected pig slurries ( $m \mathrm{FS})$, acidified slurries loaded in the greenhouse $(m \mathrm{AS})$, the final dried fraction $(m \mathrm{DF})$, and the volatilized fraction $(m \mathrm{VF})$ lost during the second drying trial. The recovery of these substances in $m \mathrm{AS}$ and $m \mathrm{DF}$, and the losses through $m \mathrm{VF}$, are also indicated in relative amounts. Significant differences between initial and recovered fractions are highlighted: $\left(^{*}\right) p<0.05 ;\left({ }^{* *}\right) p<0.01 ; n=3$.

\begin{tabular}{|c|c|c|c|c|c|c|c|}
\hline Parameter & $m \mathrm{FS}(\mathbf{k g})$ & $m \mathrm{AS}(\mathrm{kg})$ & $m \mathrm{DF}(\mathrm{kg})$ & $m \mathrm{VF}$ (kg) & $m \mathrm{AS} / m \mathrm{FS}(\%)$ & $m \mathrm{DF} / m \mathrm{AS}(\%)$ & $m \mathrm{VF} / m \mathrm{AS}(\%)$ \\
\hline Mass & $315.000(3.150)$ & $321.000(3.210)$ & $39.800(0.398)$ & $280.488^{a}$ & 102 & $12 * *$ & 89 \\
\hline Water & $281.831(3.244)$ & $\begin{array}{l}283.475 \\
(13.398)\end{array}$ & $4.139(0.041)$ & $279.366^{b}$ & 101 & $1 * *$ & 99 \\
\hline Total solids & $33.170(0.382)$ & $37.525(1.774)$ & $35.661(0.357)$ & $-{ }^{c}$ & $113 *$ & 95 & $-{ }^{c}$ \\
\hline Organic matter (COD) & $40.484(3.110)$ & $38.700(2.851)$ & $38.439(2.449)$ & $1.139^{d}$ & 96 & 99 & 3 \\
\hline Nitrogen & $2.261(0.027)$ & $2.193(0.023)$ & $1.717(0.019)$ & $0.006^{d}$ & $97 *$ & $78^{* *}$ & 0 \\
\hline Phosphorus & $0.510(0.041)$ & $0.538(0.027)$ & $0.436(0.004)$ & $-^{c}$ & 105 & $81^{* *}$ & $-{ }^{c}$ \\
\hline Potassium & $1.732(0.018)$ & $1.820(0.040)$ & $1.252(0.019)$ & $-{ }^{c}$ & 105 * & $69^{* *}$ & $-{ }^{c}$ \\
\hline Sulfur & $0.032(0.001)$ & $2.748(0.042)$ & $1.721(0.021)$ & $0.007^{d}$ & $8570 * *$ & $63^{* *}$ & 0 \\
\hline Sodium & $0.474(0.009)$ & $0.453(0.029)$ & $0.289(0.009)$ & $-^{c}$ & 96 & $64 * *$ & $-{ }^{c}$ \\
\hline Calcium & $1.732(0.024)$ & $1.820(0.032)$ & $1.252(0.007)$ & $-{ }^{c}$ & $134^{* *}$ & $29 * *$ & $-^{c}$ \\
\hline Manganese & $0.463(0.012)$ & $0.554(0.011)$ & $0.405(0.004)$ & $-{ }^{c}$ & $120 * *$ & $73^{* *}$ & $-{ }^{c}$ \\
\hline
\end{tabular}

${ }^{a}$ Sum of all the subsequently listed volatile species. ${ }^{b}$ Calculated from the water content difference between $m$ AS and $m$ DF. ${ }^{c}$ Nonvolatile fraction/compound. ' Calculated as chemical oxygen demand (COD), $\mathrm{N}$, and S equivalents from the concentration of $\mathrm{CO}_{2}, \mathrm{CH}_{4}, \mathrm{NH}_{3}$, $\mathrm{N}_{2} \mathrm{O}$, and $\mathrm{SH}_{2}$ at the greenhouse exhaust, upon subtraction of the air background concentration (Table 3).

\subsection{Fertilizer Quality Parameters of the Dried Material}

The recovered dried material at the end of the experiment had the aspect of a brownish powder with a very low water content (10.4\%) and, therefore, it exhibited a high stability during long-term storage conditions. The nutrients recovered with this fraction had a composition equivalent to a NPK index of 4.3-2.5-3.8 (mass percentage equivalent to $\mathrm{Nt}, \mathrm{P}_{2} \mathrm{O}_{5}$, and $\mathrm{K}_{2} \mathrm{O}$; Table 5). If sulfur is included in accordance to the elemental NPKS nomenclature, the resulting material would have a mass distribution ratio of 4.3-1.1-3.1-2.2. Concerning nitrogen, $68 \%$ of the total was recovered in the form of ammonium and the remaining $32 \%$ as organic nitrogen (neither nitrites nor nitrates were detected). Concerning the European regulations for fertilizing products [25], the dried material obtained in this study should be regarded as a solid organic fertilizer (Product Function Category 1A-I).

As for the content of heavy metals and metalloids, the dried fraction complies with the European acceptance criteria, but the content of zinc surpassed the thresholds for which it should be notified in the product label (Table 5). The reason for the relatively high content of zinc is because of its general use as a dietary supplement in pig feeding, as it has been shown to improve daily gain and feed conversion ratios, but it is also excreted with the dejections [26]. Zinc is an essential element for life and presents a relatively low toxicity level, but its high biotransformation potential may create accumulation exceeding 
the recommended doses in food products [27]. Testing the presence of specific human pathogenic bacteria, usually Escherichia coli and Salmonella spp., has been included in the most stringent regulations on organic fertilizers, especially for compost arising from lifestock manure [28]. The absence or very low amount of these target bacteria on the finished dried product from this study complied with these biosafety requirements (Table 5). A previous study on the composting of pig manure and straw mixtures showed that temperatures above $55^{\circ} \mathrm{C}$ for $2 \mathrm{~h}$ were sufficient for the inactivation of E. coli [29]. These conditions must have been met during the second trial under spring conditions, since the cumulative time of indoor greenhouse temperatures above $55^{\circ} \mathrm{C}$ amounted about $21 \mathrm{~h}$, but solar radiation during the first trial in autumn was insufficient to raise the temperature inside the greenhouse above this value (Figure 2).

Table 5. Fertilizer quality parameters of the dried pig slurry fraction in relation to standard threshold values for solid organic fertilizers in the European Union.

\begin{tabular}{|c|c|c|c|}
\hline Parameter & Unit & Measured Value & Regulatory Threshold $^{b}$ \\
\hline Dry matter (DM) & (\% mass) & 89 & $40(\min )$ \\
\hline $\mathrm{NPK}^{a}$ & (\% mass) & $4.3-2.5-3.8$ & $2.5-2.0-2.0(\mathrm{~min})$ \\
\hline NPKS (elemental) ${ }^{a}$ & (\% mass) & $4.3-1.1-3.1-2.2$ & - \\
\hline Organic nitrogen & (\% mass) & 32 & - \\
\hline Ammonia nitrogen & (\% mass) & 68 & - \\
\hline Cadmium & $\left(\mathrm{mg} \mathrm{kg} \mathrm{DM}^{-1}\right)$ & $<0.5$ & 1.5 \\
\hline Copper & $\left(\mathrm{mg} \mathrm{kg} \mathrm{DM}^{-1}\right)$ & 152 & $200^{c}$ \\
\hline Nickel & $\left(\mathrm{mg} \mathrm{kg} \mathrm{DM}^{-1}\right)$ & 7 & 50 \\
\hline Lead & $\left(\mathrm{mg} \mathrm{kg} \mathrm{DM}^{-1}\right)$ & $<5$ & 120 \\
\hline Zinc & $\left(\mathrm{mg} \mathrm{kg} \mathrm{DM}^{-1}\right)$ & 1357 & $600^{c}$ \\
\hline Mercury & $\left(\mathrm{mg} \mathrm{kg} \mathrm{DM}^{-1}\right)$ & $<0.4$ & 1 \\
\hline Hexavalent chromium & $\left(\mathrm{mg} \mathrm{kg} \mathrm{DM}^{-1}\right)$ & $<1$ & 2 \\
\hline Escherichia coli & $\left(\mathrm{cfu} \mathrm{gT^{-1 }}\right)$ & $<10$ & 1000 \\
\hline Salmonella spp. & (P/A $25 \mathrm{~g})$ & Absent & Absent \\
\hline
\end{tabular}

a NPK: percentage by weight of the macronutrients nitrogen, phosphorus (as phosphorus pentoxide), and potassium (as potassium oxide); NPKS: elemental mass percentage of the macronutrients nitrogen, phosphorus, potassium, and sulfur. ${ }^{b}$ Proposal for a regulation of the European Parliament and of the Council laying down rules on the making available on the market of CE marked fertilizing products and amending Regulations (EC) No 1069/2009 and (EC) No 1107/2009). ${ }^{c}$ To be declared in the label if the content is above the threshold value.

Finally, the powdery format and biochemical stability of the dried fraction facilitates its use in the manufacture of mixed organic-mineral fertilizers, upon supplementation with selected mineral nutrients, so that these final tailor-made formulations meet the specific requirements of a wide range of crops. Under the current political agenda of promoting circular economy principles, it is to be expected that the market for such mixed organic-mineral fertilizers will increase substantially in the forthcoming years.

\section{Conclusions}

We demonstrated in a pilot study that the direct exploitation of solar energy for drying pig slurries is feasible, when combined with acidification and air biofiltration for controlling ammonia loses and other gaseous emissions. The obtained dried fraction retained and concentrated the nutrients that were originally present in pig slurries, and can therefore be valorized as an organic fertilizer. Operation during relatively low solar irradiation conditions (autumn) in a Mediterranean climate was sufficient to dry pig slurries. The process efficiency improved significantly during high solar irradiation conditions (spring), and the dried product was adequately hygienized. In contrast, the operation was clearly not viable during winter time due to the low solar radiation, so that slurry storage capacity or alternative manure treatment systems would be needed to compensate for the differences in the treatment rates.

Our results also highlight the necessity to implement specific measures to regulate and reduce the dietary use of zinc in farm animals, so that organic fertilizers with high quality parameters can be manufactured. Further research on the solar drying of animal 
dejections is focused on the mathematical modeling of the process in order to maximize the process efficiency through optimized design parameters and operational conditions. The mixing of partially dried pig slurries was also identified as a convenient improvement for a large-scale implementation, in order to break the formation of crusted agglomerates and to homogenize the water content along the greenhouse. Alternative acidification strategies (organic acids, bioacidification) to prevent sulfide emissions and reduce operational costs, as well as agronomical assays with dried fractions, are presently being performed to validate and improve this innovative treatment technology.

Supplementary Materials: The following are available online at https:/ / www.mdpi.com/2073-439 5/11/2/222/s1, Table S1: Meteorological data.

Author Contributions: Conceptualization, J.S. and F.X.P.-B.; methodology, J.N.; formal analysis, J.I.; investigation, B.F. and M.V.; resources, J.S.; writing-original draft preparation, F.X.P.-B.; writingreview and editing, J.I.; supervision, F.X.P.-B. All authors have read and agreed to the published version of the manuscript.

Funding: This research received no external funding.

Institutional Review Board Statement: Not applicable.

Informed Consent Statement: Not applicable.

Data Availability Statement: Data will be made available upon request.

Acknowledgments: This research was supported by the CERCA Programme/Generalitat de Catalunya. The assistance of the Catalan Ministry of Agriculture, Livestock, Fisheries and Food is also acknowledged. The authors from IRTA and the Universitat de Lleida belong to the Consolidated Research Group TERRA (ref. 2017 SGR 1290).

Conflicts of Interest: The authors declare no conflict of interest.

\section{References}

1. Kamilaris, A.; Assumpcio, A.; Bonmatí, A.; Torrellas, M.; Prenafeta-Boldú, F.X. Estimating the environmental impact of agriculture by means of geospatial and big data analysis: The case of Catalonia. In From Science to Society: New Trends in Environmental Informatics; Otjacques, B., Hitzelberger, P., Naumann, S., Wohlgemuth, V., Eds.; Springer International Publishing: Cham, Switzerland, 2018; pp. 39-48.

2. Val del Río, A.; Carrera Fernández, P.; Campos Gómez, J.L.; Mosquera-Corral, A. Nutrients pollution in water bodies: Related legislation in Europe and the United States. In Technologies for the Treatment and Recovery of Nutrients from Industrial Wastewater; Val del Río, A., Campos Gómez, J., Mosquera Corral, A., Eds.; IGI Global: Hershey, PA, USA, 2017; pp. $21-42$.

3. Hjorth, M.; Christensen, K.V.; Christensen, M.L.; Sommer, S.G. Solid-liquid separation of animal slurry in theory and practice. In Sustainable Agriculture; Lichtfouse, E., Hamelin, M., Navarrete, M., Debaeke, P., Eds.; Springer Netherlands: Dordrecht, The Netherlands, 2011; Volume 2, pp. 953-986.

4. Romero-Güiza, M.S.; Tait, S.; Astals, S.; Del Valle-Zermeño, R.; Martínez, M.; Mata-Alvarez, J.; Chimenos, J.M. Reagent use efficiency with removal of nitrogen from pig slurry via struvite: A study on magnesium oxide and related by-products. Water Res. 2015, 84, 286-294. [CrossRef] [PubMed]

5. Bonmati, A.; Flotats, X. Pig slurry concentration by vacuum evaporation: Influence of previous mesophilic anaerobic digestion process. J. Air Waste Manag. Assoc. 2003, 53, 21-31. [CrossRef] [PubMed]

6. VijayaVenkataRaman, S.; Iniyan, S.; Goic, R. A review of solar drying technologies. Renew. Sustain. Energy Rev. 2012, 16, $2652-2670$. [CrossRef]

7. Sharma, A.; Chen, C.R.; Vu Lan, N. Solar-energy drying systems: A review. Renew. Sustain. Energy Rev. 2009, 13, 1185-1210. [CrossRef]

8. El-Sebaii, A.A.; Shalaby, S.M. Solar drying of agricultural products: A review. Renew. Sustain. Energy Rev. 2012, 16, 37-43. [CrossRef]

9. Singh, P.; Shrivastava, V.; Kumar, A. Recent developments in greenhouse solar drying: A review. Renew. Sustain. Energy Rev. 2018, 82, 3250-3262. [CrossRef]

10. Pirasteh, G.; Saidur, R.; Rahman, S.M.A.; Rahim, N.A. A review on development of solar drying applications. Renew. Sustain. Energy Rev. 2014, 31, 133-148. [CrossRef]

11. Prenafeta-Boldúm, F.X.; Burgos, L.; Noguerol, J.; Mercader, M.; Soler, J.; Fernández, B. Solar drying in the vineyard: A sustainable technology for the recovery of nutrients from winery organic waste. Water Sci. Technol. 2020, 82, 27-38. 
12. Ghaly, A.; Alhattab, M. Drying poultry manure for pollution potential reduction and production of organic fertilizer. Am. J. Environ. Sci. 2013, 9, 88. [CrossRef]

13. O'Shaughnessy, S.A.; Song, I.; Artiola, J.F.; Choi, C.Y. Nitrogen loss during solar drying of biosolids. Environ. Technol. 2008, 29, 55-65. [CrossRef] [PubMed]

14. Battista, F.; Bolzonella, D. Exploitation of solar energy for ammonium sulfate recovery from anaerobic digestate of different origin. Waste Biomass Valori. 2019, 10, 3701-3709. [CrossRef]

15. Fangueiro, D.; Hjorth, M.; Gioelli, F. Acidification of animal slurry-A review. J. Environ. Manag. 2015, 149, 46-56. [CrossRef] [PubMed]

16. APHA; AWA; WEF. Standard Methods for the Examination of Water and Waste Water, 21th ed.; American Public Health Association/American Water Works Association/Water Environment Federation: Washington, DC, USA, 2005.

17. USEPA. Method 1103.1: Escherichia coli (E. coli) in Water by Membrane Filtration Using Membrane-Thermotolerant Escherichia coli Agar (mTEC); US Environmental Protection Agency: Washington, DC, USA, 2006.

18. USEPA. Method 1682: Salmonella in Sewage Sludge (Biosolids) by Modified Semisolid Rappaport-Vassiliadis (MSRV) Medium; US Environmental Protection Agency: Washington, DC, USA, 2006.

19. Palatsi, J.; Illa, J.; Prenafeta-Boldú, F.X.; Laureni, M.; Fernandez, B.; Angelidaki, I.; Flotats, X. Long-chain fatty acids inhibition and adaptation process in anaerobic thermophilic digestion: Batch tests, microbial community structure and mathematical modelling. Bioresour. Technol. 2010, 101, 2243-2251. [CrossRef] [PubMed]

20. Martínez-Eixarch, M.; Alcaraz, C.; Viñas, M.; Noguerol, J.; Aranda, X.; Prenafeta-Boldú, F.X.; Saldaña-de la Vega, J.A.; Català, M.d.M.; Ibáñez, C. Neglecting the fallow season can significantly underestimate annual methane emissions in Mediterranean rice fields. PLoS ONE 2018, 13, e0198081.

21. Prenafeta-Boldú, F.X.; Parera, J. Guia de les Tecnologies de Tractament de les Dejeccions Ramaderes a Catalunya; Parera, J., Ed.; Departament d'Agricultura, Ramaderia, Pesca i Alimentació (DARP): Barcelona, Spain, 2020.

22. Amoore, J.E.; Hautala, E. Odor as an aid to chemical safety: Odor thresholds compared with threshold limit values and volatilities for 214 industrial chemicals in air and water dilution. J. Appl. Toxicol. 1983, 3, 272-290. [CrossRef] [PubMed]

23. Rosenfeld, P.E.; Clark, J.J.; Hensley, A.R.; Suftet, I.H. The use of an odour wheel classification for the evaluation of human health risk criteria for compost facilities. Water Sci. Technol. 2007, 55, 345-357. [CrossRef] [PubMed]

24. Balsari, P.; Santoro, E.; Dinuccio, E.; Gioelli, F. Assessment of the performances of different mechanical solid-liquid separators for pig and cattle slurries. In DIAS Deport Plant Production; Danish Institute of Agricultural Sciences: Tjele, Denmark, 2006; pp. 157-159.

25. European Commission. Proposal for a Regulation of the European Parliament and of the Council Laying Down Rules on the Making Available on the Market of CE Marked Fertilising Products and Amending Regulations (EC) No 1069/2009 and (EC) No 1107/2009; European Commission: Brussels, Belgium, 2016.

26. Dourmad, J.-Y.; Jondreville, C. Impact of nutrition on nitrogen, phosphorus, $\mathrm{Cu}$ and $\mathrm{Zn}$ in pig manure, and on emissions of ammonia and odours. Livestock Sci. 2007, 112, 192-198. [CrossRef]

27. Lopes, C.; Herva, M.; Franco-Uría, A.; Roca, E. Inventory of heavy metal content in organic waste applied as fertilizer in agriculture: Evaluating the risk of transfer into the food chain. Environ. Sci. Pollut. Res. 2011, 18, 918-939. [CrossRef] [PubMed]

28. Hogg, D.; Barth, J.; Favoino, E.; Centemero, M.; Caimi, V.; Amlinger, F.; Devliegher, W.; Brinton, W.; Antler, S. Comparison of Compost Standards within the EU, North America and Australasia; Main Report; The Waste and Resources Action Programme: Banbury, Oxon, UK, 2002.

29. Turner, C. The thermal inactivation of E. coli in straw and pig manure. Bioresour. Technol. 2002, 84, 57-61. [CrossRef] 